\title{
Layanan Bimbingan dan Konseling AUD Berbasis Tugas Perkembangan untuk Meningkatkan Perilaku Prososial
}

\author{
Chitra Charisma Islami , Eva Gustiana \\ Pendidikan Guru Pendidikan Anak Usia Dini \\ STKIP Muhammadiyah Kuningan \\ chitra@upmk.ac.id
}

\begin{tabular}{l}
\hline Info Artikel \\
\hline Sejarah Artikel: \\
Diterima (Juli) (2020) \\
Disetujui (Juli) (2020) \\
Dipublikasikan (Juli) (2020) \\
\hline Keywords: \\
Layanan BK AUD; Tugas \\
Perkembangan; \\
Perilaku Prososial
\end{tabular}

\begin{abstract}
Abstrak
Penelitian ini bertujuan (1) mengetahui layanan BK di Kober Rabbani, Kuningan; (2) menghasilkan layanan BK berbasis tugas perkembangan untuk meningkatkan perilaku prososial yang sesuai di Kober Rabbani Kuningan. Metode penelitian: Research and Development (R\&D). Subjek penelitian 10 anak. Teknik dan instrumen pengumpulan data: (1) Studi dokumenter (2) Wawancara, dan (3) angket. Analisis data yang digunakan yaitu teknik deskriptif. Kesimpulan penelitian: (1) layanan BK di Rabbani Kuningan tidak melalui asesmen kebutuhan. Pelaksanaan layanan BK kurang memaksimalkan guru di sekolah. (2) layanan BK berbasis tugas perkembangan yang sesuai digunakan pada anak Kober Rabbani adalah layanan yang dikembangkan brerdasarkan asesmen kebutuhan anak, kondisi sekolah dan kebutuhan lingkungan (harapan guru dan orang tua).
\end{abstract}

\begin{abstract}
This study discusses (1) Knowing BK services in Kober Rabbani, Kuningan; (2) produce BK services based on appropriate development tasks to improve prosocial behaviour in Kober Rabbani Kuningan. Research methods: Research and Development (R\&D). Research subjects 10 children. Data conversion techniques and instruments: (1) Documentary studies (2) Interviews, and (3) questionnaires. Analysis of the data used is descriptive technique. Research conclusions: (1) BK services at Rabbani Kuningan cannot be requested. Implementation of BK services is not optimal at school. (2) Development-based $B K$ services suitable for use by Kober Rabbani children are services that are developed based on the assessment of children's needs, school needs and environmental needs (expectations of teachers and parents).
\end{abstract}




\section{Pendahuluan}

Salah satu penelitian yang berjudul Prosocial Spending and Well-Being: CrossCultural Evidence for a Psychological Universa (Norton \& Michael I, 2013). Penelitian Norton dan Michael ini memberikan dukungan perkembangan ilmu psikologi bahwa manusia di dunia ini merasa memiliki manfaat emosional dengan menampilkan perilaku prososial.

Sementara itu, (Sari, 2013) dalam penelitian yang menggunakan metode penelitian dan pengembangan (Research and Development) memaparkan bahwa berdasarkan hasil uji lapangan diketahui bahwa model bimbingan kelompok dengan teknik sosiodrama terbukti efektif dalam meningkatkan sikap prososial siswa. Hasil yang signifikan output $=0.00<5 \%$, yang berarti ada perbedaan yang signifikan antara sikap prososial siswa sebelum diberikan perlakuan (pre-test) dan setelah pengobatan yang diberikan (post-test). Salah satu upaya yang perlu dilakukan untuk membantu siswa meningkatkan sikap prososial dengan mengoptimalkan bimbingan kelompok.

Krisis perilaku prososial dialami oleh semua lapisan masyarakat. Seperti yang telah disampaikan oleh (Rosen dkk, 2010) bahwa dengan adanya perilaku prososial akan mengurangi adanya perilaku agresif, yang mana perilaku agresif ini akan menghambat keberhasilan seseorang dalam hidupnya.

Salah satu usaha yang bisa diupayakan adalah melalui jalur pendidikan. Tujuan pendidikan seutuhnya adalah membantu siswa mencapai perkembangan secara optimal. Jadi bisa dimaknai bukan hanya aspek kognitif atau akademik saja yang perlu ditingkatkan dalam pendidikan. Akan tetapi semua aspek termasuk di dalamnya aspek non kognitif yang meliputi aspek afektif dan psikomotornya.

Disisi lain mengapa perlu di terapkannya layanan bimbingan konseling di semua jenjang pendidikan dikarenakan proses pengalaman belajar dan pembelajaran di tingkat pendidikan usia dini dan sekolah dasar akan berpengaruh terhadap perilaku di masa depannya di tingkat sekolah menengah pertama, sekolah menengah atas maupun tingkat perguruan tinggi. Jadi proses layananan bimbingan konseling merupakan suatu proses berkelanjutan yang di perlukan agar kondisi siswa dapat tetap di kontrol dengan baik.

Masa anak adalah masa emas bagi pertumbuhan dan perkembangan berbagai potensi yang dimiliki, baik aspek agama-moral, fisik-motorik, kognitif, bahasa, sosio- 
emosianal, dan lain sebagainya. Masa anak juga dikenal dengan masa kritis yang oleh David A. Sousa (dalam Putra dan Dwilestari, 2012) dikenal dengan konsep jendela peluang, yaitu "periode ketika otak memerlukan jenis-jenis masukan tertentu untuk menciptakan atau menstabilkan struktur yang bertahan lama".

Undang-Undang Sistem Pendidikan Nasional (UU Sisdiknas) nomor 20 tahun 2003 bab 1 pasal 1 ayat 6 menegaskan, "pendidik adalah tenaga kependidikan yang berkualifikasi sebagai guru, dosen, konselor, pamong belajar, widyaswara, tutor, instruktur, fasilitator, dan sebutan lain yang sesuai dengan kekhususannya, serta berpartisipasi dalam menyelenggarakan pendidikan".

Salah satu bentuk pendidikan anak usia dini adalah Kelompok Bermain yang disingkat Kober maupun KB. Pendidikan di Kober menjadi tugas bersama seorang guru. Konselor adalah pendidik, sehingga memiliki peran dan fungsi dalam pendidikan dan pembimbingan anak usia dini. Fungsi dan peran konselor pada pendidikan anak usia dini termasuk di Kober didukung oleh Peraturan Pemerintah nomor 27 tahun 2008 tentang Standar Kualifikasi Akademik dan Kompetensi Konselor (SKAKK) yang menegaskan "konselor adalah pengampu pelayanan ahli bimbingan dan konseling, terutama dalam jalur pendidikan formal dan nonformal". Pendidikan taman kanakkanak adalah salah satu jalur pendikan formal.

Peran konselor dalam memberikan layanan bimbingan dan konseling (BK) di PAUD perlu diaplikasikan melalui perencanaan kerja yang di rumuskan dalam program bimbingan dan konseling yang tepat guna. Tentunya program yang di rumuskan berorientasi pada perkembangan yang menyentuh kebutuhan aspek perkembangan sesuai dengan tugas-tugas perkembangan pada setiap tahapan perkembangan anak. (Santoadi, 38) menyatakan, "jika program bimbingan berorientasi perkembangan (developmental), maka konsekuensinya adalah pengelolaan program bimbingan dan konseling mengharuskan layanan bimbingan dan konseling mengembangkan seluruh aspek dalam diri peserta didik". Sayangnya saat ini penyelengaraan bimbingan di PAUD kurang menekankan aspek perkembangan secara keseluruhan, apalagi menekankan tahapan dan tugas perkembangan secara sistematis.

Kondisi awal di Kober Rabbani terdapat beberapa perilaku siswa yang tidak sesuai dengan perkembangannya, siswa yang tidak mau meminjamkan pensil (alat tulis) kepada temannya, anak yang tidak mau meminta maaf ketika bersalah, beberapa anak tidak mau antri ketika pembagian alat peraga oleh gurunya. 
Merujuk pada beberapa paparan di atas, semakin jelas perlu adanya layanan BK yang tersusun secara sistematis untuk memfasilitasi dan menstimulasi perkembangan anak secara optimal. Perlu diaplikasikan melalui peyusunan program yang menyentuh tugas perkembangan anak sesuai dengan tahapan perkembangan. Maka dari itu layanan BK yang dirasakan mendesak adalah layanan BK berbasis tugas-tugas perkembangan.

\section{Metode Penelitian}

Pada penelitian ini, peneliti menggunakan metode dan desain penelitian dan pengembangan (research and development) yang didasarkan pada prinsip-prinsip dan langkah-langkah dari Borg \& Gall.

(Borg \& Gall, 1983) langkah-langkah yang harus ditempuh dalam penelitian dan pengembangan, antara lain: (a) studi pendahuluan, (b) perencanaan, (c) pengembangan model hipotetik, (d) penelaahan model hipotetik, (e) revisi, (f) uji coba terbatas, (g) revisi hasil uji coba, (h) uji coba lebih luas, (i) revisi model akhir, dan (j) diseminasi dan sosialisasi. Namun, dalam penelitian ini kesepuluh langkah tersebut akan dimodifikasi menjadi enam langkah yang disesuaikan dengan kebutuhan penelitian.

\section{Hasil Penelitian}

Berdasarkan hasil analisis data dengan Wilcoxon menunjukkan bahwa tujuan dari model layanan bimbingan konseling Kober berbasis tugas perkembangan untuk meningkatkan perilaku prososial tercapai, yakni dengan adanya perubahan hasil evaluasi awal dan hasil evaluasi akhir pada perilaku prososial yang dimiliki oleh anak Kober Rabbani Kuningan.

Kaidah yang digunakan adalah menguji hipotesis alternatif $(\mathrm{Ha})$ yang berbunyi layanan bimbingan konseling anak usia dini berbasis tugas perkembangan untuk meningkatan perilaku prososial. Berdasarkan hasil pengujian wilcoxon, diperoleh perbedaan sebesar -3.625 pada nilai signifikansi hitung (sig.2taled) 0,001. Perbandingan nilai signifikansi hitung dengan pada taraf signifikansi $5 \%(0,05)$ adalah 0,001 < 0,05 sehingga hipotesis nihil (Ho) ditolak sedangkan hipotesis alternatif (Ha) diterima. Sehingga terbukti efektif untuk meningkatkan perilaku prososial siswa. 


\section{Hasil}

Perbandingan nilai evaluasi awal dan evaluasi akhir siswa keseluruhan secara rinci ditampilkan dalam Tabel dibawah ini.

Tabel 1. Perbandingan Skor Evaluasi Awal dan Evaluasi Akhir

\begin{tabular}{lllllll}
\hline No & Siswa & $\begin{array}{l}\text { Evaluas } \\
\text { i Awal }\end{array}$ & $\begin{array}{l}\text { Evaluas } \\
\text { i Akhir }\end{array}$ & $\begin{array}{l}\text { Perubahan } \\
\text { Skor }\end{array}$ & Ket. & Perubahan Kategori \\
\hline 1 & 001 & 135 & 166 & 31 & 16,85 & $\begin{array}{l}\text { sangat rendah menjadi } \\
\text { rendah }\end{array}$ \\
2 & 002 & 141 & 169 & 28 & 15,22 & sedang menjadi tinggi \\
3 & 003 & 130 & 164 & 34 & 18,48 & rendah menjadi sedang \\
4 & 004 & 145 & 175 & 30 & 16,30 & sedang menjadi tinggi \\
5 & 005 & 136 & 161 & 25 & 13,59 & rendah menjadi sedang \\
6 & 006 & 137 & 166 & 29 & 15,76 & sedang menjadi tinggi \\
7 & 007 & 133 & 161 & 28 & 15,22 & rendah menjadi tinggi \\
8 & 008 & 142 & 176 & 34 & 18,48 & sedang menjadi tinggi \\
9 & 009 & 131 & 164 & 33 & 17,93 & sedang menjadi tinggi \\
10 & 010 & 125 & 158 & 33 & 17,93 & $\begin{array}{l}\text { sangat rendah menjadi } \\
\text { rendah }\end{array}$ \\
\hline
\end{tabular}

Perilaku prososial siswa pada seluruh indikator mengalami peningkatan sejumlah 146 poin setelah diberikan perlakuan. Artinya bahwa layanan bimbingan konseling anak usia dini berbasis tugas perkembangan efektif meningkatkan perilaku prososial.

Hasil perbandingan skor antara evaluasi awal dan evaluasi akhir di atas dikuatkan dengan hasil uji wilcoxon pada tabel di bawah ini 
Tabel 2. Hasil Perhitungan Wilcoxon

\begin{tabular}{lcccc}
\hline & & $N$ & Mean Rank & Sum of Ranks \\
\hline Evaluasi Awal- & Negative & $0^{a}$ & .00 & .00 \\
Evaluasi Akhir & Ranks & $17^{b}$ & 9.00 & 153.00 \\
& Positive Ranks & $9 c$ & & \\
& Ties & 26 & & \\
& Total & & & \\
\hline
\end{tabular}

Test Statistic

\begin{tabular}{ll}
\hline & $\begin{array}{l}\text { Evaluasi Akhir- } \\
\text { Evaluasi Awal }\end{array}$ \\
\hline$Z$ & $-3.625^{a}$ \\
Asymp.Sig. (2-tailed) & .001 \\
\hline
\end{tabular}

\section{Diskus}

Krisis perilaku prososial dialami oleh semua lapisan masyarakat. Seperti yang telah disampaikan oleh (Rosen dkk, 2010) bahwa dengan adanya perilaku prososial akan mengurangi adanya perilaku agresif, yang mana perilaku agresif ini akan menghambat keberhasilan seseorang dalam hidupnya.

Hasil penelitian terkait dengan layanan BK di Kober Rabbani Kuningan yang diperoleh melalui wawancara dengan guru Kober Rabbani Kuningan menunjukkan bahwa pengelolaan layanan BK di Kober Rabbani Kuningan belum pernah dilakukan secara terprogram. Dan perencanaan dan perumusan layanan BK tidak berdasarkan needs assesment, kurangnya sosialisasi dalam pelaksanaan program sehingga peran personel sekolah dan stakeholder lain yang berkepentingan kurang maksimal. Evaluasi tidak dipersiapkan secara maksimal, sehingga tujuan evaluasi kurang jelas dan evaluasi tidak diadministrasikan dalam bentuk laporan evaluasi program. Secara rinci hasil penelitian terkait dengan layanan BK di Kober Rabbani Kuningan yang selanjuatnya dijadikan tolok ukur pengembangan layanan BK di Kober Rabbani. 
Berdasarkan analisis data, dapat disimpulkan bahwa secara umum, TKTP anak Kober Rabbani Kuningan mencakup: 1) terdapat sebanyak 2 anak termasuk kategori tingkat ketercapaian tugas-tugas perkembangan "sangat tinggi", 2) terdapat sebanyak 4 anak termasuk kategori tingkat ketercapaian tugas-tugas perkembangan "tinggi", 3) terdapat sebanyak 4 anak termasuk kategori tingkat ketercapaian tugas-tugas perkembangan "rendah".

Dalam rangka menjalankan fungsi pemeliharaan, secara umum layanan BK diberikan kepada semua anak, baik anak dengan TKTP yang termasuk kategori "rendah" maupun yang termasuk kategori "tinggi".

Dalam rangka pengembangan layanan BK berbasis tugas-tugas perkembangan, maka peneliti membutuhkan masukan dari beberapa pihak khususnya yang terlibat dalam kegiatan bimbingan, yaitu melalui kegiatan Focus Group Discussion (FGD. Selanjutnya validasi produk dengan meminta meminta pakar/ahli (expert judgement) guru Kober Rabbani, dosen Prodi PG-PAUD STKIP Muhammadiyah Kuningan serta dosen Pengampu Mata Kuliah Bimbingan dan Konseling di STKIP Muhammadiyah Kuningan dalam kegiatan Focus Group Discussion (FGD).

\section{Simpulan}

Simpulan penelitian: (1) layanan BK belum dilaksanakan secara terprogram di Kober Rabbani Kuningan dan tidak melalui needs asessment terkait ketercapaian tugastugas perkembangan anak. (2) layanan BK berbasis tugas-tugas perkembangan yang sesuai digunakan pada anak Kober Rabbani Kuningan adalah program BK yang memfasilitasi dan menstimulasi ketercapaian tugas perkembangan anak yang difokuskan ke dalam peningkatan perilaku prososial anak mencakup: a) berempati, b) dermawan. (3) Setelah dilakukan layanan BK untuk meningkatkan perilaku prososial anak kober Rabbani mengalami peningkatan dalam berperilaku prososial.

\section{Daftar Pustaka}

ABKIN. (2008). Penataan Pendidikan Profesional Konselor dan Layanan Bimbingan dan Konseling dalam Jalur Pendidikan Formal. Direktorat Jenderal Pendidikan Tinggi : Departemen Pendidikan Nasional

Afolabi, Olukayode Ayooluwa. (2014). Psychosocial Predictors Of Prosocial Behaviour Among A Sample Of Nigerian Undergraduates. European Scientific Journal January 2014 edition vol.10, No.2 ISSN: 1857 - 7881 (Print) e - ISSN 1857- 7431 
Albert, A. Paul., T. Thilagavathy., (2013). A Study on Pro-Social Behaviour and Parental Behaviour of Higher Secondary Students. International Journal of Science and Research (IJSR). ISSN (Online): 2319-7064

Arikunto, S. (2010). Prosedur Penelitian suatu Pendekatan Praktik. Edisi Revisi. Jakarta : Rineka Cipta

Baron, Robert A. \& Byrne, Donn. (2005). Psikologi Sosial. Jakarta : Erlangga

Borg, Walter R. \& Gall, Meredith Damien. (1983). Educational Research : An Introduction. New York and London ; Longman

Dayakisni, T. \& Hudaniah. (2009). Psikologi Sosial. Malang: UMM Press

Desmita. (2014). Psikologi Perkembangan Peserta Didik. Bandung: PT. Remaja Rosdakarya.

Fatimah, E. (2008). Psikologi Perkembangan Siswa. Bandung : Pustaka Setia

Gibson Robert L., \& Mitchell Marianne H., (2011). Bimbingan dan Konseling. Yogyakarta: Pustaka Pelajar

Gladding Samuel T., (2012). Konseling: Profesi yang Menyeluruh. Edisi Keenam. Jakarta: Indeks.

Juntika Nurihsan. (2011). Bimbingan dan Konseling dalam Berbagai Latar Kehidupan. Bandung: Refika Aditama.

King, Laura A. (2010). Psikologi Umum : Sebuah Pandangan Apresiasif. Jakarta : Salemba Humanika

Martin, DYP Sugiharto, Sukiman. (2014) Program Bimbingan dan Konseling (BK) Berbasis Tugas-Tugas Perkembangan di Taman Kanak-Kanak (TK). E-ISSN: 25024531. https://journal.unnes.ac.id/sju/index.php/jubk/article/view/3621

Norton, Michael I., (2013). Prosocial Spending and Well-Being: Cross-Cultural Evidence for a Psychological Universal. Journal of Personality and Social Psycholog. American Psychological Association. Vol. 104, No. 4, 635-652

Olson, Matthew H. (2013). Pengantar Teori-teori Kepribadian, Edisi Kedelapan. Yogyakarta : Pustaka Pelajar

Purwanto, Edi. (2013). Metode Penelitian Kuantitatif. Fakultas Ilmu Pendidikan Universitas Negeri Semarang

Republik Indonesia. Undang-Undang Nomor 20 Tahun (2003). Sistem Pendidikan Nasional. Bandung : Citra Umbara

Santrock, John W. (2012). Life-Span Development (Perkembangan Masa-Hidup) Edisi Ketigabelas Jilid 1. Jakarta : Erlangga

Sari, Erlina Permata. (2013). Pengembangan Model Layanan Bimbingan Kelompok dengan Teknik Sosiadrama untuk Meningkatkan Sikap Prososial. ISSN 2252-6889. http://journal.unnes.ac.id//sju/index.php/i 
Sugiyono. (2010). Metode Penelitian Pendidikan, Pendekatan Kualitatif, Kuantitatif dan $R$ $\& D$. Bandung : Alfabeta

Winkel \& M. Sri Hastuti. (2006). Bimbingan dan Konseling. Yogyakarta : Media Abadi

Yusuf, Syamsu dan Juntika Nurihsan. (2010). Landasan Bimbingan \& Konseling. Cetakan kelima. Bandung: PT. Remaja Rosdakarya.

Yusuf, Syamsu. (2009). Program Bimbingan dan Konseling di Sekolah. Bandung: Rizzqi Press 